\section{U.K. Atomic Energy Authority and Central Electricity Generating Board Co-operation Scheme}

To facilitate the close co-operation which already exists between the United Kingdom Atomic Energy Authority and the Central Electricity Generating Board, it has been decided that there should be cross-membership between the two bodies. Mr. F. Cousins, Minister of Technology, has accordingly appointed Mr. E. S. Booth, the engineering member of the Central Electricity Generating Board, to be a part-time member of the Atomic Energy Authority, and Mr. F. Lee, Minister of Power, has appointed Mr. J. C. C. Stewart, the Member for Reactors of the Atomic Energy Authority, to be a part-time member of the Central Electricity Generating Board.

\section{Professional and Technical Staff in the Civil Service}

IN a recent issue of State Service, the journal of the Institution of Professional Civil Servants (August 1965), the general secretary, M. W. McCall, commenting on the 1964 report of the Civil Service Commission, stresses the continuous failure to recruit sufficient professional and technical staff. Candidates could only be recommended for about a third of basic grade vacancies for engineers, although two-thirds of the vacancies at main grade and higher levels were filled. Similarly, while two-thirds of the vacancies for architects in these grades were filled, only one-sixth of those at the basic grade were filled. Only 85 out of 220 vacancies for mechanical and electrical engineers were filled and only 327 out of 546 vacancies in the technical classes. The Board of Inland Revenue is stated to be short of a fifth of its complement of professional valuers, the work of the Patent Office is delayed for a like reason, and the shortage of Factory Inspectors has been reflected for years in the low frequency of inspections. To remedy this situation, Mr. MeCall urges that pay and careers must be offered to scientists, technologists and technicians which indicate that they are no longer regarded as inferior or second-and third-rate. Their training and talents should be used to the field in terms of the work they are qualified to do and they should have full opportunity of promotion to the highest posts.

\section{Aid to Education Overseas}

The Overseas Development Institute has issued the report of a Ditchley Foundation Conference held at Ditchley Park during March 26-29, 1965 (Aid to Education: An Anglo-American Appraisal. Report of a Ditchley Foundation Conference held at Ditchley Park, March 26-29, 1965. Rapporteur: Peter Williams. Pp. 52. London: The Overseas Development Institute, in association with The Ditchley Foundation, 1965. 3s. 6d.). Dealing with educational aid, especially in Africa, Asia, and the Caribbean, it considers first the donor programmes and policies of educational aid, and second the requirements of the recipient countries. Next it sets forth some conclusions about priorities and the principles of educational aid before making specific suggestions for future Anglo-American co-operation in this field. Recognizing the neod for a balance between education and the economy, the Conference gave much thought to the determination of priorities between types and levels of education. It also emphasized that educational aid is a two-way process and that the developing countries should not copy too rigidly the institutions and techniques of developed countries. It is emphasized that the developing countries will need educational assistance for a very long time ahead. The Conference strongly urged that Britain and the United States should, as the major donor countries, prepare themselves to meet the challenge by establishing permanent resource centres on which to draw in their aid programme.

It suggests that it would be wise to establish small cadres of experts on a permanent footing and to create supernumerary posts in Government departments, universities and other institutions. Moreover, appropriate arrangements should be made for training the personnel involved, so that specialists could be seconded for overseas assignments as required. In this way a permanent supply of experts would be ensured. The advantages of involving non-government institutions are also emphasized, as well as the need for a strategy of educational aid. It is suggested that existing forms of co-operation, like the Teachers for East Africa Scheme and programmes of joint support for overseas universities, should be extended and supplemented by new schemes. Specific areas for future co-operation should include the development of curricula and text-books, the teaching of English, application of modern techniques (like educational television and programme learning), educational research, the training of teachers, experiments in comprehensive secondary school education and work on methods of reducing the costs of education. Pilot projects and experiments should be financed so far as possible by aid donors. Direct linking of American, British and overseas teachertraining institutes for various purposes is recommended as well as co-ordination of British and American programmes for teacher refresher courses in developing countries.

\section{Water Affairs in Zambia}

THE independence of Zambia came about in 1964 and inevitably brought with it great changes in the administration and conduct of the work of official organizations concerned with development of natural resources, including water. The Department of Water Affairs had to adjust itself to the new conditions, and how it set about this task is revealed in the recently published annual report of the Departmont of Water Affairs for the year 1964 (Pp. 9. Lusaka: Grovernment Printer, 1965. 2s.). One of the major difficulties which had to be faced was the loss to the Water Department of many well-trained and experienced members of the professional and technical staff who decided to leave the country and seek a new life elsewhere. The report devotes considerable attention, and rightly so, to the serious staff position thus created. Notwithstanding this handicap, and the rather alarming number of vacancies existing in the various grades of water engineers and technical staff, actually 39 at the close of 1964, the amount of development work accomplished in many areas now under regional planning, including investigation and construction of new water works, appears quite remarkable. Special mention is made of the work of the Hydrological Branch in respect of the Kafue Basin Survey, where an investigation of the river system was considerably extended by installation of many new stations chiefly in the area between Mumbwa and the Copperbelt. Good progress was also made in rehabilitation of old drainage canals and also in construction of new canals in Barotseland. It is recorded that there has since been a notable improvement in drainage of areas affected by these works; crops can now be grown where formerly the land was far too wet. Further sections of the report summarize the present position of the Copperbelt water supply; other work of the Hydrological Branch; water projects in view; water communications and drainage in the Bangweulu Swamps; drainage and communications in Barotseland; the functions of the Water Board and of the Geological and Drilling Sections.

\section{Scientific Research in the Development of Folish Industry}

IN the Review of the Polish Academy of Sciences for January-March 1965, I. Malecki describes the role of scientific rosearch in the development of Polish industry since the Second World War. The period 1945-52 was 